\title{
DIVERSIFIED INCOME ANALYSIS OF COCONUT AND ARECA NUT FARMING IN MENDAHARA DISTRICT OF TANJUNG JABUNG TIMUR, INDONESIA
}

\author{
Sativa Fendria, Herdiyansyah Rikky, Teaching Staff \\ Department of Agribusiness, Faculty of Agriculture, UNJA, Indonesia \\ E-mail: fendria2000@gmail.com
}

\begin{abstract}
This study aims to: 1) analyze differences in income from diversification of coconut and areca nut farming based on age groups; 2) analyze the contribution of the commodity of coconut and areca nut to the income diversification of coconut and areca nut farming based on age groups; 3) analyze the feasibility of diversification of coconut and areca nut farming based on various ages. The research site is determined intentionally (purposive). The data used in this study are primary data and secondary data. The sample selection is determined using the snowball sampling method. The analytical method used in this study is descriptive qualitative analysis. The result showed that: 1) Diversified income from coconut and areca nut farming in different age groups was different. The average income of coconut farming in the largest group is 15 to 19 years, amounting to $R p .20,640,336 /$ ha/year and the average age group of areca nut farming is 12 years with amount $\mathrm{Rp} .12,616,501 / \mathrm{Ha} / Y e a r .2)$ The result of the average research contribution of income from diversification of coconut and areca nut farming is the contribution of coconut farming greater (59.44\%) than the contribution of areca nut farming (40.56\%). 3) Diversification of coconut and areca nut farming in each age group is feasible. The average result of $\mathrm{R} / \mathrm{C}$ coconut farming ration in the study area was 4,67 is in the 15-19 years age group. The average result of $\mathrm{R} / \mathrm{C}$ value of areca nut farming in the study area was 3.05 which is in the average age group of 12 years.
\end{abstract}

\section{KEY WORDS}

Coconut, farming, income, production value.

Coconut is one of the plantation commodities that have many advantages, since almost all of its parts can be utilized. Starting from the fruit flesh, coir, shell, coconut water, stems, sticks, even the roots of the coconut have economic values (Bustami et al., 2014). Coconut production in Jambi Province tends to be stable and not affected by other commodities that are popular in the community such as palm oil. Coconut is the third commodity that has the largest area and production after oil palm and rubber with an area of 118,543 hectares and production of 104,528 tons (BPS, 2017). Coconut has characteristics that are easily cultivated both monoculture, and diversification with other plants.

Coconut commodities in Jambi Province are mostly cultivated horizontally diversified. Coconut itself has been cultivated monoculture by farmers since 1984. Diversification of coconut with areca nut in Jambi Province began in 2000, which is the recommendation of the Tanjung Jabung Regency Government. Recommendations are made to take advantage of the empty space found among the coconut plants cultivated at a distance of $8 \times 8$ meters (Bustami et al., 2014)

One of the biggest coconut and areca nut production centers in Tanjung Jabung Timur Regency is in Mendahara District. Mendahara District has an area of coconut trees of 21,604 hectares and a production of 18,013 tons. Meanwhile, betel commodity in Mendahara District has an area of 2,777 hectares and a production of 1,097 tons. The survey results in Mendahara Subdistrict, Tanjung Jabung Timur Regency found that most of the coconut commodities were cultivated diversified with areca nut commodity. The coconut and areca nut commodity are superior commodities which are the main sources of farmers' income. Diversification of coconut and areca nut farming is carried out horizontally diversification.

The income of coconut and areca nut farming certainly has differences in each age group of plants. This is caused since each coconut and areca nut farming is having different 
production for each age of the plant. Therefore, it is necessary to study how much income of coconut and areca nut farming in each age group. Based on the results of the initial survey in Mendahara District, Tanjung Jabung Timur Regency, the age group of coconut plants can be grouped into four patterns; from 10-14 years old, 15-19 years old, 20-24 years old and $\geq 25$ years old. The age group interval is based on the opinion of Foale \& Harries (2009), that coconuts in the peak production period range from 15-20 years. After 20 years of age its production has gradually declined and after 40 years of age its production has declined. This is the basis for age groups to be distinguished by age intervals of 5 years. The division of age groups based on coconut plants is because the coconut commodity in the first planted as the main crop, while the betel commodity as an intercrop can be calculated only based on the age of the areca nut plant found in each age group of the coconut plant.

Judging from the potential of the diversification of coconut and areca nut farming, there is deeper interest in further researching the concept of contribution. Contributions can be interpreted as contributions made to meet and meet family income needs. The contribution in this case is how much the percentage of contribution of coconut and areca nut farming that results from diversification of coconut and areca nut farming in each age group of coconut and areca nut.

Likewise, to determine the diversification of coconut and areca nut farming is feasible or not to be cultivated. According to Sunarjono (2000) farming is profitable or feasible if farming analysis shows decent results. A farm can be said to be feasible or not to be cultivated, it can be seen from the efficient use of costs and the magnitude of the ratio between total revenues to total costs. Therefore, it is necessary to further analyze the level of feasibility based on various age groups in the diversification of coconut and areca nut farming in Mendahara District, Tanjung Jabung Timur Regency.

Based on the description above, this study aims to: 1) Analyze the differences in income from diversification of coconut and areca nut farming based on age groups in Mendahara District, Tanjung Jabung Timur Regency; 2) Analyzing the contribution of the commodity of coconut and areca nut to the income diversification of coconut and areca nut farming based on age groups in Mendahara District, Tanjung Jabung Timur Regency; 3) Analyzing the feasibility of diversification of coconut and deep nut farming based on age varies in Mendahara District, Tanjung Jabung Timur Regency.

\section{METHODS OF RESEARCH}

This study was conducted in Mendahara District, Tanjung Jabung Timur Regency. The selection and determination of the location is done intentionally (purposive) with consideration of the amount of area and production of coconut and areca nut farming in Mendahara District is the highest in Tanjung Jabung Timur Regency. This research was conducted from July $24^{\text {th }} 2018$ until August $24^{\text {th }} 2018$. This study was conducted in 3 villages (kelurahan) namely Kelurahan Mendahara Ilir, Sungai Tawar and Desa Mendahara Tengah. Data collected in this study include primary data and secondary data. Primary data obtained from interviews with farmers based on a list of questions / questionnaire. Whereas secondary data is obtained from library studies by taking data from books, journals and scientific papers that have been recorded and published. The object that will be observed in this study is farmers who are trying to diversify the farming of coconut and areca nut which are divided based on 4 age groups of coconut plants. Determination of the number of samples from the population is determined by the snowball sampling method which is as many as 60 respondents divided by the age of the coconut plant, namely the age group of 10-14 years, the age group of 15-19 years, the age group of 20-24 years and the age group $>25$ years.

The use of income analysis is intended to determine the amount of income derived from the diversification of coconut and areca nut farming. The formulas used in this analysis are (Hernanto, 1996):

$$
Y=y 1+y 2
$$


Where: $Y=$ Total Farm Income $(R p) ; y 1=$ Coconut farming income $(R p)$; $y 2=$ Areca nut farming income (Rp).

The formula for calculating Coconut Farming Income (y1), is:

$$
\mathrm{y} 1=\mathrm{TR}-\mathrm{TC}
$$

Where: $y 1=$ Income of coconut farming (Rp); TR = Total Acceptance of coconut farming $(\mathrm{Rp}) ; \mathrm{TC}=$ Total Cost of coconut farming (Rp).

The formula for calculating areca farming income $(\mathrm{y} 2)$, is:

$$
\text { y2 }=\text { TR }-\mathrm{TC}
$$

Where: $y 2$ = Areca farming income $(R p) ; T R=$ Total Acceptance of areca nut farming $(R p)$; $\mathrm{TC}=$ Total cost of areca nut farming (Rp).

To calculate the total revenue (TR) of coconut farming and areca nut, the formula is used:

$$
\mathrm{TR}=\mathrm{Y} . \mathrm{Py}
$$

Where: $\mathrm{Y}=$ production $(\mathrm{kg})$; $\mathrm{Py}=$ Price received $(\mathrm{Rp} . / \mathrm{Kg})$.

Meanwhile, to calculate the total expenditure (TC) of coconut farming and areca nut, the formula is used:

$$
\mathrm{TC}=\mathrm{FC}+\mathrm{VC}
$$

Where: FC = Fixed fee (Rp); VC = Variable Cost $(R p)$.

Calculating the amount of farming contribution to the diversification of coconut and areca nut farming can use the following formula (Widodo, 1995):

$$
\mathrm{KU}=\frac{\mathrm{PU}}{\mathrm{PT}} \times 100 \%
$$

Where: $\mathrm{KU}=$ Contribution of farming to total farm income (\%); PU = Farm income (Rp); $\mathrm{PT}=$ Total revenue $(\mathrm{Rp})$.

Calculating the feasibility analysis of coconut farming and areca nut can use the following formula (Suratiyah, 2011):

$$
\begin{gathered}
a=R / C \\
R=P y \cdot Y \\
C=F C+V C \\
a=(P y . Y) /(F C+V C)
\end{gathered}
$$

Where: $\mathrm{R}=$ Acceptance; $\mathrm{C}=$ Cost; $\mathrm{Py}=$ Output Price; $\mathrm{Y}=$ Output; $\mathrm{FC}=$ Fixed Costs; $\mathrm{VC}=$ Variable Cost.

The indicators are as follows:

- If the $R / C$ is $<1$, then the farming is not feasible;

- If $R / C>1$, the farming is feasible.

\section{RESULTS AND DISCUSSION}

Diversification of agriculture is an effort to replace or increase monoculture agricultural output towards multicultural agriculture. Such diversification is called horizontal diversification. The main reason for the diversification effort is the stabilization in agricultural income and avoiding dependence on just one or two types of commodities (Mubyarto, 1977). Diversification of coconut and areca nut farming in Mendahara District is carried out by 
planting areca nut plants between the coconut trees. This diversification is carried out by most farmers who work on coconut trees.

The coconut and areca nut commodity are superior commodities which are the main sources of farmers' income. Diversification of coconut and areca nut farming is carried out horizontally diversification. Initially most of the farmers in Mendahara sub-district only worked on coconut commodities, but the magnitude of the economic need that was not enough was only dependent on coconut farming and over time the price of areca-based commodities began to soar so that many farmers initially sought only coconut commodities making decisions to diversify horizontally in coconut commodity with areca nut commodity. The areca nut commodity functions as an intercrop planted between rows of coconut trees. This is an effort to increase farmers' income because farmers want to have a greater income by maximizing coconut land in a way by diversifying coconut and areca nut.
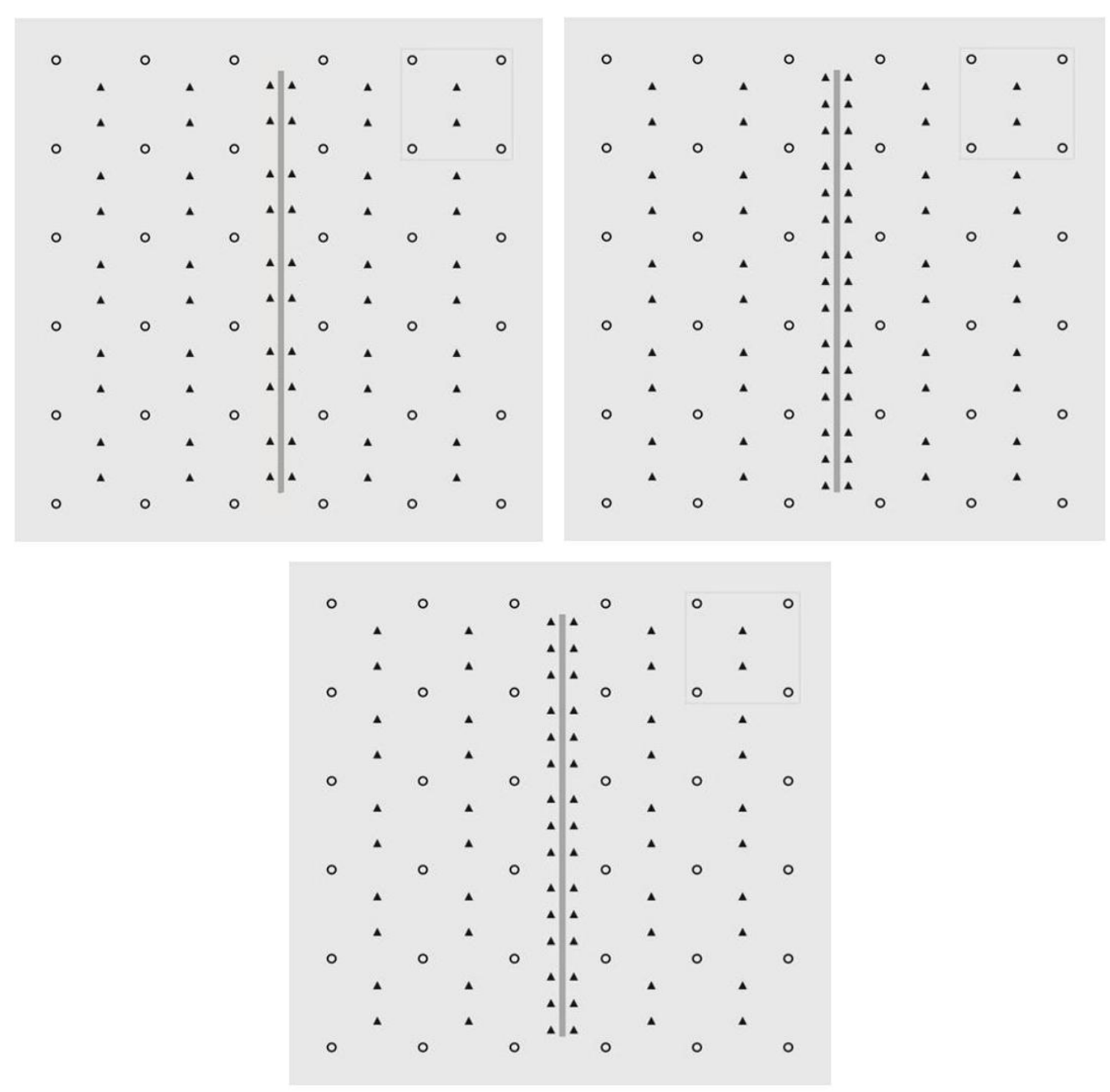

Note:

Figure 1 - Diversification Patterns of Coconut with Areca Nut Palm

$$
\begin{aligned}
& \hat{\boldsymbol{A}}=\text { Coconut } \\
& \mathbf{I}=\text { Areca Nut } \\
& \text { I Garden Trench }
\end{aligned}
$$

Farming pattern is a method used by farmers in commercializing land owned by coconut and areca nut. The pattern used by the sample farmers in this study site was square $(7 \mathrm{~m} \times 7 \mathrm{~m})$. Based on the planting pattern each hectare the number of coconut plants is \pm 204 trees. Calculation of one hectare of coconut land is 6 rows of coconut with a garden length of \pm 34 coconut trees. Meanwhile, the areca nut plant is between the coconut trees in the middle of the square between the coconut tree and the areca nut plant, also planted 
along the side of the trench with a distance of $2 \times 2$ meters. When calculated areca nut plants contained in one hectare of diversified land is \pm 476 trees.

Maintenance is a mandatory activity that must be carried out by farmers so that their farming is successful and produces good production. Maintenance of coconut in the study site consisted of several activities including eradication of weeds, cleaning trenches for drainage. Plant maintenance activities are carried out every 3 months for eradication of weeds and once every 6 months for cleaning trenches for drainage.

Implementation of farming activities that include maintenance activities to harvest and sell the production of coconut requires labor. Labor will be a variable cost of farming activities with coconut areca nut and affect the size of the income earned by farmers. The average labor cost in maintenance activities, which is eradication of weeds, is $\pm \mathrm{Rp}$. 200,000 / ha and in the ditch clearing for drainage \pm Rp. 300,000 / ha.

Coconut harvesting is done generally every three months, while areca nut harvesting is done generally every month. The coconut harvesting activity starts from 5-8 years old coconut plants. Harvesting activities are carried out by respondent farmers on average 3-4 times a year. Harvesting activities are carried out using bamboo and sickle because the height of coconut plants reaches an average of 20 meters with a labor wage of \pm Rp. 100,000 / row of coconut in a. Old coconut fruit, marked by the color of the skin of the fruit that has turned brown and dry. Coconut fruit is collected by flowing the fruit through a ditch found in the coconut garden using a machete and a coconut spear. Areca harvesting activities are carried out faster than in coconut farming, which is every month. The criteria for betel nuts that are ready to harvest (old) is that the skin of the betel nut has turned yellow or reddish, then some have fallen off the tree or the fruit is 7-8 months old. Areca harvesting activities through a process ranging from harvesting activities using bamboo and sickle with labor costs \pm Rp.200,000 / ha, then collected and put into sacks using labor wages \pm Rp.100,000 / HK.

Most of the respondents $(51,66 \%)$ owned farmland with an area of more than the average $(1.7 \mathrm{Ha})$ of farmer land area, amounting to $36.67 \%$ had land area is still relatively low and only $11.67 \%$ had land area average. The lowest land area is $0.3 \mathrm{Ha}$ and the highest land area is $4.7 \mathrm{Ha}$. The area of land owned by farmers is their own land. This shows that most farmers in the study area still carry out small-scale farming in the size of smallholder plantations, thus this study is relevant to the opinion of Hernanto (1996) which states that smallholder farming is in relatively small agriculture.

The age of coconut and areca nut plants is the age of coconut and areca nut plants managed by farmers from the time of planting to when the research is carried out. The age of coconut and areca nut plants can affect the production of coconut and areca nut. Based on research results in the study area coconut age lowest 10 years and highest 45 years, and the age of the lowest areca nut plant 5 years and the highest 25 years.

Income analysis is needed to calculate how much income is received from the diversification of coconut and areca nut farming. Analysis of income is calculated based on the amount of revenue minus the cost of production incurred. Income obtained is calculated based on the age group of plants so that it will be seen the age group of plants that provide the highest income among other age groups of plants. Diversification income for coconut and areca nut farming can be seen in the following table:

Table 1 - Average Income of Diversification of Coconut and Pinang Farms by Age Group in the Study Area in 2018

\begin{tabular}{ccccc}
\hline & Coconut & \multicolumn{2}{c}{ Areca Nut } & \multicolumn{2}{c}{ Coconut \& Areca Nut } \\
\hline Plant Age (Th) & Income (Rp/Ha/Th) & Average Age (Th) & Income (Rp/Ha/Th) & $\begin{array}{c}\text { Total Income } \\
(\mathrm{Rp} / \mathrm{Ha} / \mathrm{Th})\end{array}$ \\
\hline $10-14$ & 5.206 .110 & 9 & 5.076 .502 & 10.282 .612 \\
$15-19$ & 20.630 .336 & 12 & 12.616 .501 & 33.246 .837 \\
$20-24$ & 15.263 .176 & 14 & 8.361 .912 & 23.625 .088 \\
$\geq 25$ & 11.434 .220 & 15 & 7.470 .067 & 18.904 .287 \\
\hline
\end{tabular}

Source: Result of Primary Data Processed in 2018. 
Based on Table 1, it can be seen that coconut income for each age group is different. The results showed that the highest average coconut income in the study area is Rp. $20,630,336$ / ha / year, in the age group of 15-19 years. Similarly, areca nut income at different ages is different. The highest average areca nut income in the study area was Rp. $12,616,501$ / Ha / Year at an average age of 12 years. The total income of the diversification of coconut and areca nut farming in each age group also varies. The results of the study showed that the average income of diversification of coconut and areca nut farming was highest in the study area of Rp. 33,246,837 / ha / year, in the coconut age group of 15-19 years and the average age of areca nut is 12 years. The majority of income differences in each age group of plants are due to the significant differences in crop production in each age group.

The contribution of diversification of coconut and areca nut farming is the contribution or role given by the diversification of coconut and areca nut farming which is cultivated by farmers to the overall income. Through these contributions, it can be seen how much the contribution made by each farm to the overall farm income. Revenue contribution is useful for knowing which businesses have the biggest and most reliable shares in the future. The calculation can be done by dividing the income of each farm by the total farm income derived from total income and multiplied by one hundred percent.

Table 2 - Contribution of Coconut and Areca Diversification Income by Age Group in the Study Area 2018

\begin{tabular}{ccccc}
\hline \multicolumn{2}{c}{ Coconut } & \multicolumn{2}{c}{ Areca Nut } & Coconut \& Areca Nut \\
\hline Plant Age (Th) & Contribution (\%) & Average Age (Th) & Contribution (\%) & Total Contribution (\%) \\
\hline $10-14$ & 50,63 & 9 & 49,37 & 100 \\
$15-19$ & 62,05 & 12 & 37,95 & 100 \\
$20-24$ & 64,61 & 14 & 35,39 & 100 \\
$\geq 25$ & 60,48 & 15 & 39,52 & 100 \\
\hline Average & 59,44 & & 40,56 & 100 \\
\hline
\end{tabular}

Source: Result of Primary Data Processed in 2018.

Based on Table 2 it can be seen that the average contribution of income from diversification of coconut and areca nut farming in each age group is that the contribution of coconut farming is greater than that of areca nut farming. The results of the study showed that the average contribution of income from the diversification of coconut and areca nut farming in the study area was that the contribution of coconut farming was greater $(59.44 \%)$ than the contribution of areca nut farming (40.56\%). The contribution of diversification of coconut and areca nut farming to each age group of plants is influenced by the income received from the revenue less the production costs for each crop. Coconut farming income is greater than areca nut farming income which causes the contribution of coconut farming revenue is greater than areca nut farming.

The feasibility analysis of the diversification of coconut and areca nut farming is carried out to determine whether the farming is feasible or not. Whether or not the diversification of coconut and areca nut farming can be known is by calculating the ratio of revenue to costs ( $\mathrm{R}$ / C ratio). The $\mathrm{R} / \mathrm{C}$ ratio shows how much revenue will be obtained from each rupiah spent in the diversified production of coconut and areca nut farming. Ratio analysis of production costs can be used to measure the relative feasibility of the farming activity. This means that from the ratio of revenue to these costs it can be seen whether the diversification of coconut and areca nut farming is feasible or not. Diversification of coconut and areca nut farming is said to be feasible if the $R / C$ ratio is greater than one $(R / C>1)$ which means that any additional costs incurred will result in greater additional income or simply diversification of coconut and areca nut farming is profitable and feasible. If the $R / C$ ratio is less than one $(\mathrm{R} / \mathrm{C}<1)$, it means that the additional costs incurred will result in an additional income that is smaller than the additional costs or simply diversification of the coconut and areca nut farming to suffer losses and are not worth the effort. The $\mathrm{R} / \mathrm{C}$ ratio of the diversification of coconut and areca nut farming is calculated based on age groups to see differences in the 
feasibility of each age group and age group which gives a higher feasibility value among other age groups.

Table 3 - R / C Ratio of Diversification of Coconut and Areca Palm Farming by Age Group in the Study Area in 2018

\begin{tabular}{cccc}
\hline Coconut & & \multicolumn{2}{c}{ Areca Nut } \\
\hline Age Plant (Th) & R/C Ratio & Average Age (Th) & R/C Ratio \\
\hline $10-14$ & 2,43 & 9 & 2,45 \\
$15-19$ & 4,67 & 12 & 3,05 \\
$20-24$ & 4,07 & 14 & 2,75 \\
$\geq 25$ & 3,69 & 15 & 2,65 \\
\hline
\end{tabular}

Source: Result of Primary Data Processed in 2018.

Based on Table 3 it can be seen that the average $R$ / $C$ ratio of the diversification of coconut and areca nut farming in each age group is different and the diversification of coconut and areca nut farming in each age group is feasible to be cultivated. The results of research on average the highest $R / C$ ratio of coconut farming in the study area was 4.67 in the age group of 15-19 years, this means that each sacrifice was Rp. 1 will generate Rp. 4.67. Similarly, the results of research on average the highest $\mathrm{R} / \mathrm{C}$ ratio value of areca nut farming in the study area was 3.05, namely in the average age group of 12 years, this means that each sacrifice of Rp. 1 will generate Rp. 3.05. The difference in the $\mathrm{R} / \mathrm{C}$ ratio of each age group of plants is due to differences in revenue for different costs in each age group.

\section{CONCLUSION}

Based on the results of research and discussion, it can be concluded that the income of diversified coconut and areca nut farming generated in each age group is different. The highest income generated in the age group of coconut farming in 15-19 years was Rp.20,630,336 / Ha / Year and the average age group of 12 years areca nut farming was Rp.12,616,501 / Ha / Year. The contribution of diversification of coconut and areca nut farming in each age group can be concluded that the contribution of coconut farming is greater than areca nut farming. The results of the study showed that the average contribution of income from the diversification of coconut and areca nut farming in the study area was that the contribution of coconut farming was greater (59.44\%) than the contribution of areca nut farming (40.56\%). Diversification of coconut and areca nut farming in each age group is feasible. The results of the study average the highest $R / C$ ratio of coconut farming in the study area was 4.67 in the age group of $15-19$ years. The highest average R / C ratio of areca nut farming in the study area was 3.05 , which was in the average age group of 12 years.

\section{REFERENCES}

1. BPS. 2017. Jambi Dalam Angka 2017. BPS Provinsi Jambi. Jambi.

2. Bustami, Mildaerizanti dan Jumakir 2014. Usahatani Kelapa Dalam di Lahan Pasang Surut Sungai Kepayang Tanjung Jabung Barat. Jurnal Prosiding Konferensi Nasional Kelapa VIII.

3. Foale, M and Harries. 2009. Coconut: Specialty Crops for Pasific Island Agroforesty.

4. Hernanto, F. 1996. IImu Usahatani, Penebar Swadaya. Jakarta.

5. Mubyarto. 1977. Pengantar Ekonomi Pertanian. LP3S. Jakarta.

6. Sunarjono. 2000. Teori Ekonomi Produksi, Raja Grafindo Persada. Jakarta.

7. Suratiyah, K. 2011. Ilmu Usahatani. Penebar Swadaya. Jakarta.

8. Widodo. 1995. Ekonomi Indonesia dalam Era Liberalisasi. Kanisius. Yogyakarta. 